\title{
Experimental Examination and Modification of Chip Suction System in Circular Sawing Machine
}

\section{Eksperimentalno ispitivanje i modifikacija sustava za odsis drvnih čestica na kružnoj pili}

\author{
Original scientific paper • Izvorni znanstveni rad \\ Received-prispjelo: 10. 7. 2017. \\ Accepted-prihvaćeno: 13. 6. 2018. \\ UDK: $630 * 822.331 .9$ \\ doi:10.5552/drind.2018.1743
}

\begin{abstract}
The article presents the results of experimental examination of the wood chip suction system in the existing sliding table saw before and after its modification. The studies focused on the extraction hood of the mentioned system. The methodical experimental research of the pressure distribution inside the hood during wood chip removal for the selected rotational speed of saw blades of 3500 and $6000 \mathrm{~min}^{-1}$ with a diameter of $300 \mathrm{~mm}$ and $450 \mathrm{~mm}$ were carried out. The analysis of the results allowed estimating the areas with insufficient vacuum pressure hindering the organized transport of wood chips in the sliding table saw. That pressure was the main factor influencing the decision to adjust the hood construction. To achieve the efficient performance, several changes in the hood geometry were implemented. The results obtained from the experiments were used at the stage of shape modification of the extraction hood. As a result, a new design of the chip suction system was obtained, vastly improving the chip extraction from the tool.
\end{abstract}

Key words: sliding table saw, chip removing system, experimental study

SAŽETAK • U radu su prikazani rezultati eksperimentalnog istraživanja sustava za odsis drvnih čestica na stolnoj kružnoj pili prije njegove izmjene i nakon nje. Istraživanja su bila usmjerena na usisno ušće istraživanog sustava. Provedeno je metodološko eksperimentalno istraživanje raspodjele tlaka unutar usisnog ušća tijekom rada sustava za odsis drvnih čestica pri brzini vrtnje kružne pile od 3500 i 6000 min $^{-1} i$ uz promjer lista pile od $300 i$ $450 \mathrm{~mm}$. Analiza rezultata omogućila je procjenu područjâs nedovoljnim podtlakom unutar kojih je onemogućen učinkovit odsis drvnih čestica na stolnoj kružnoj pili. To je i bio glavni razlog odluke o prilagodbi konstrukcije usisnog ušća. Kako bi se postigao učinkovit odsis drvnih čestica, napravljeno je nekoliko promjena u geometriji usisnog ušća. Rezultati dobiveni eksperimentalnim istraživanjem upotrijebljeni su u fazi modificiranja oblika usisnog ušća. Kao rezultat toga dobiven je novi dizajn usisnog ušća kojim je znatno poboljšan odsis drvnih čestica iz radnog prostora alata.

Ključne riječi: stolna kružna pila, sustav za odsis drvnih čestica, eksperimentalna istraživanja

\footnotetext{
${ }^{1}$ Authors are assistant professors at the Gdansk University of Technology, Faculty of Mechanical Engineering, Department of Energy and Industrial Apparatus, Gdansk, Poland. ${ }^{2}$ Author is a full professor at the Gdansk University of Technology, Faculty of Mechanical Engineering, Department of Manufacturing Engineering and Automation, Gdansk, Poland. ${ }^{3}$ Author is a chief process engineer in REMA SA in Reszel, Poland.

Autori su docenti Tehnološkog sveučilišta u Gdansku, Strojarski fakultet, Odjel za energetske i industrijske uređaje, Gdansk, Poljska. ${ }^{2}$ Autor je redoviti profesor Tehnološkog sveučilišta u Gdansku, Strojarski fakultet, Odjel za energetske i industrijske uređaje, Gdansk, Poljska. ${ }^{3} \mathrm{Au}-$ tor je glavni procesni inženjer u tvrtki REMA SA, Reszel, Poljska.
} 


\section{INTRODUCTION}

\section{UVOD}

Currently, design development of woodworking machines, introduction of new technologies, and above of all the machining and feed speed result in the need to provide more effective wood waste (chips) removing systems. A modern wood cutting machine, which operates without a properly designed suction system loses immediately its performance and service life (Barański et al., 2016). Woodworking machines and cutting parameters as well as wood material properties strongly determine the particle size distribution of chipped wood.

In the technological processes of machine wood chipping, a by-product is also formed besides the main product. These are chips whose shape, size and amount mainly depend on the form, physical and mechanical properties of sawed wood as well as on the shape, dimensions, type of machine, sharpness of the cutting blade, and technical and technological conditions of the sawing process (Wasielewski, 1999; Wasielewski and Orlowski, 2002; Orłowski, 2010; Beljo Lučić et al., 2005; Očkajova et al., 2006; Kopecký and Rousek, 2007; Klement and Detvaj, 2007).

Particles of wood, which are formed in individual processes of chipping and machining, are called "bulk wood substance" (Dzurenda, 2007). Thus, wood industry workers exposed to airborne wood dust particles in the surrounding air of the workplace may face different occupational health hazards (Kohler, 1995). Actually, the nature of the production and properties of chips require their continuous removal from the place where they are formed. As far as sanding dust is concerned, it is removed by means of an air-technical device - suction system. To develop such an appropriate suction system, it is important to know the size and shape of bulk particles, which are the basic data for characterizing the bulk material. The above characteristics affect the physical and mechanical properties of the bulk material (bulk density, bulk angle, tilt angle, aerodynamic properties of particles in the piping of the suction system) and conditions of separation or filtration in the separating device (Dzurenda, 2007). Also, those characteristics strongly affect the service life of the equipment in the workplace, where dust is generated as well as transportation equipment and filtering elements and, last but not least, the safety of the working environment.

Many authors investigate the possibility of reducing the (airborne) particles by controlling the machining parameters and by varying the cutting speed, feed speed, tool type and tool size, cutting angles, number of blades and processed material (Fujimoto and Takano, 2003; Hemmilä et al., 2003). According to the results of these researches, the average chip thickness is one of the most important parameters of wood machining (Wieloch and Osajda, 2007). Furthermore, the sanding process, as a major source of airborne dust, was investigated by Rogoziński and Dolny, 2004; Očkajová and Beljaková, 2004; Beljaková and Očkajová, 2007; Rončka and Očkajová, 2007).
Depending on the machine type and the shape and size of its dust zone, serious problems may arise concerning the effective discharge of dust through a suction system during certain sanding positions. The machine type and method of processing significantly influence the increase of dust concentration in the air (Kos et al., 2004). It is very difficult to remove dust when the working zone is large and when the tool operates at relatively high velocity. The dispersion of chips in different directions in the space of the treatment zone is very unfavorable in this respect. When the movement direction of the chips created during machining does not coincide with that of the air flow created by an extraction system, many chips are still not removed and can become dispersed in the air surrounding the machine. This takes places during sawing when the whole tool goes into the material piece. For this reason, there are problems with the direct removal of chips from the working zone and working tools. The dispersion of chips in all directions also occurs due to the high-speed rotation of those tools.

Wood working enterprises, as sources of air pollution, emit into the air wood dust classified as solid pollutants. Clean Air for Europe is the initiative taken by the EU Commission, by which one of its main aims set in 2002 was: "To reach such a quality of the environment where the level of pollutants coming from human activities does not cause any significant impacts and risks for human health" (EU Decision, 2002).

In this paper, experimental investigations of the wood chip removing system for sliding table saw were performed. The aim of the study was to examine chip suction system in the existing machine, commercially available on the market. Special attention was focused on its extraction hood without influence of fan parameters. The changes in a hood design have been proposed, causing higher efficiency of the chip removing system, which was confirmed by the results of experimental research.

\section{MATERIALS AND METHODS} 2. MATERIJALI I METODE

The sampling of pressure measurements was carried out during circular saw operation without machining. Table 1 shows the parameters of saw blades used during experiments.

The measurements were performed using the wide and narrow cover mounted in the hood of the suction-chip removing system and the saw blades of different diameter and rotational speed. For the saw blade No. 1, two of its maximum and minimum rotational speeds of $3500 \mathrm{~min}^{-1}$ and $6000 \mathrm{~min}^{-1}$, and for saw blade No. 2, its nominal rotational speed of $3500 \mathrm{~min}^{-1}$ were considered, respectively. Variable fan speed was achieved by changing fan motor frequency. The relative static pressure was measured using a digital multifunction measuring instrument. The temperature, humidity and air flow meter Testo 480 (TESTO SE \& Co., Germany) was applied. The results were averaged for 10 seconds at each measuring point. Measuring 
Table 1 Parameters of woodworking machine saw blades during experiments

Tablica 1. Parametri listova pila na stroju za obradu drva proučavanih u eksperimentu

\begin{tabular}{|c|c|c|}
\hline $\begin{array}{l}\text { Woodworking machine } \\
\text { Stroj za obradu drva }\end{array}$ & $\begin{array}{c}\text { Circular saw No. } 1 \\
\text { Kružna pila } 1 .\end{array}$ & $\begin{array}{c}\text { Circular saw No. } 2 \\
\text { Kružna pila } 2 .\end{array}$ \\
\hline Tool diameter / promjer alata, $D(\mathrm{~mm})$ & $\varnothing 300$ & $\varnothing 450$ \\
\hline Number of teeth / broj zubi, z & 96 & 72 \\
\hline Tooth height / visina zubi, $h(\mathrm{~mm})$ & 9.82 & 19.63 \\
\hline Overall set (kerf width) / širina propiljka, $S_{t}(\mathrm{~mm})$ & 3.2 & 4.4 \\
\hline Thickness of saw blade / debljina lista pile, $a(\mathrm{~mm})$ & 2.2 & 3.2 \\
\hline Rotational speed / brzina vrtnje, $n\left(\mathrm{~min}^{-1}\right)$ & 3500 & 3500 \\
\hline
\end{tabular}

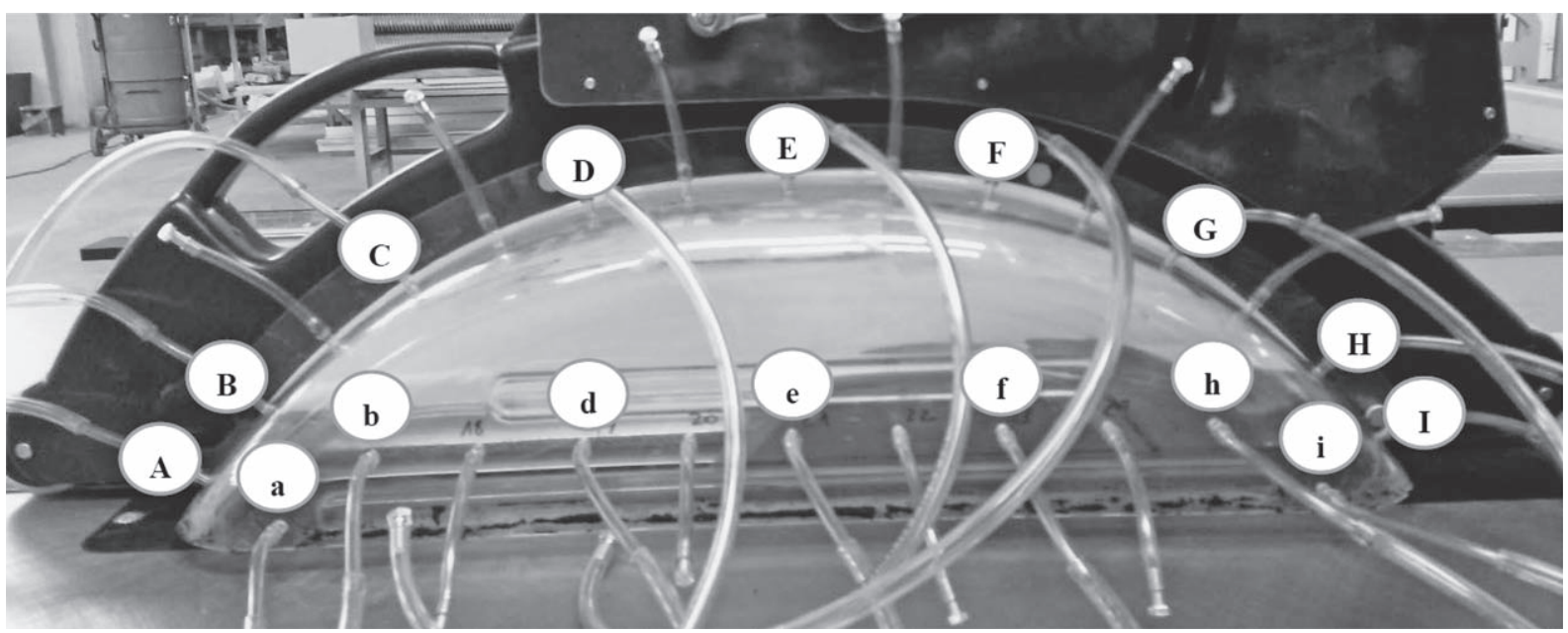

Figure 1 Location of measurement points on a wide cover of the hood

Slika 1. Raspored mjernih mjesta na širokom poklopcu usisnog ušća

range was from -10 to $+10 \mathrm{kPa}$, resolution $0.01 \mathrm{kPa}$ and accuracy $\pm 0.3 \mathrm{~Pa}+1 \%$ of the value measured in the lower range. Velocity at the entrance to the hood, as well as to the bottom shelter, was measured using the same instrument, with a hot wire probe. Measuring range was $0-20 \mathrm{~m} / \mathrm{s}$, resolution $0.01 \mathrm{~m} / \mathrm{s}$ and accuracy $\pm 0.03 \mathrm{~m} / \mathrm{s}+5 \%$ of the measured value.

Experimental tests consisted of measuring the relative static pressure distribution zero-referenced against ambient air pressure at several points on the wide and narrow cover of suction-chip extraction hood (points "A"-"I" on the upper part and "a"-"i" on the side part of the wide cover and points " $\mathrm{b}^{*}$ "- $\mathrm{h}$ *" on the side of narrow cover). Locations of all measuring points are shown in Fig. 1 and Fig. 2. During preliminary measurements, more points were considered. However, it was found that there was a small pressure difference between the points situated close to each other.

The obtained results were analyzed and verified by the experiments performed using different shapes of the upper hood, Fig. 3.

\section{RESULTS AND DISCUSSION 3. REZULTATI I RASPRAVA}

Results of relative static pressure measurements for the wide and narrow cover mounted in the hood of the existing system, further referred to as "base case", showed that at most of the measurement points there was a vacuum pressure, as expected. However, some

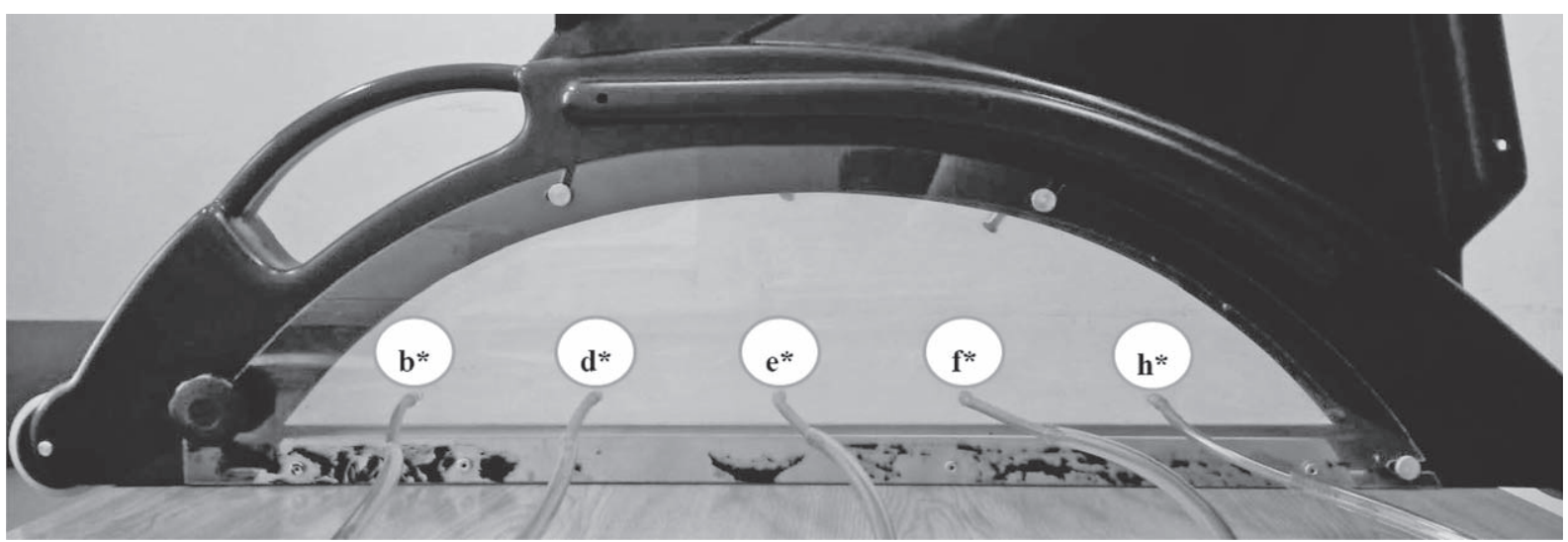

Figure 2 Location of measurement points on a narrow cover of the hood

Slika 2. Raspored mjernih mjesta na uskom poklopcu usisnog ušća 


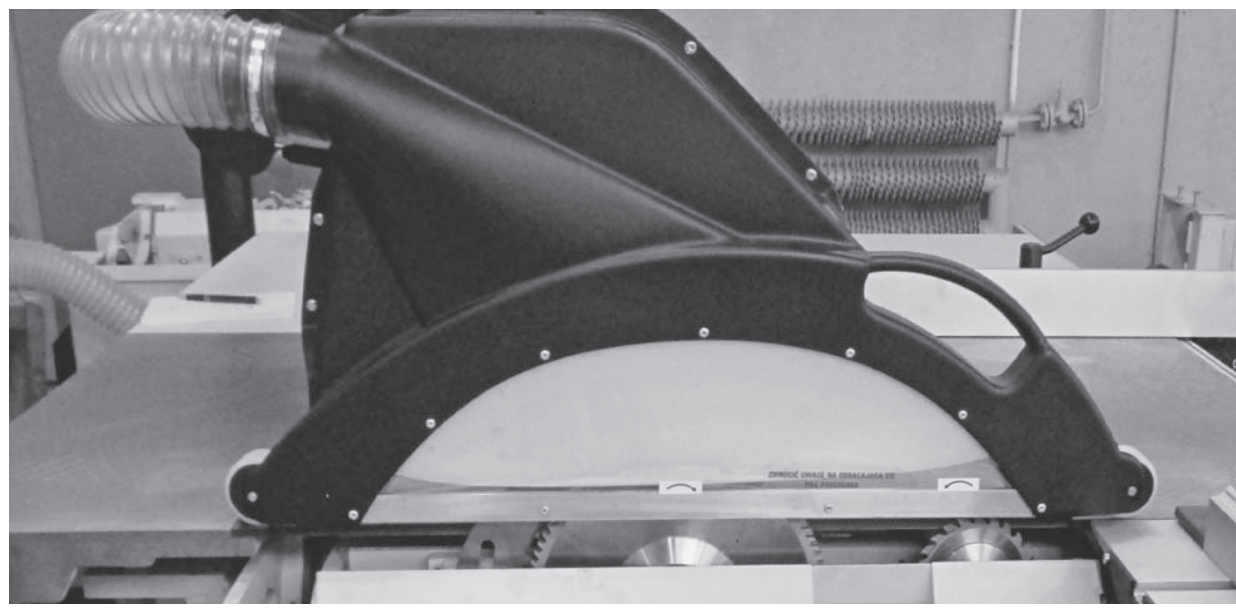

a)

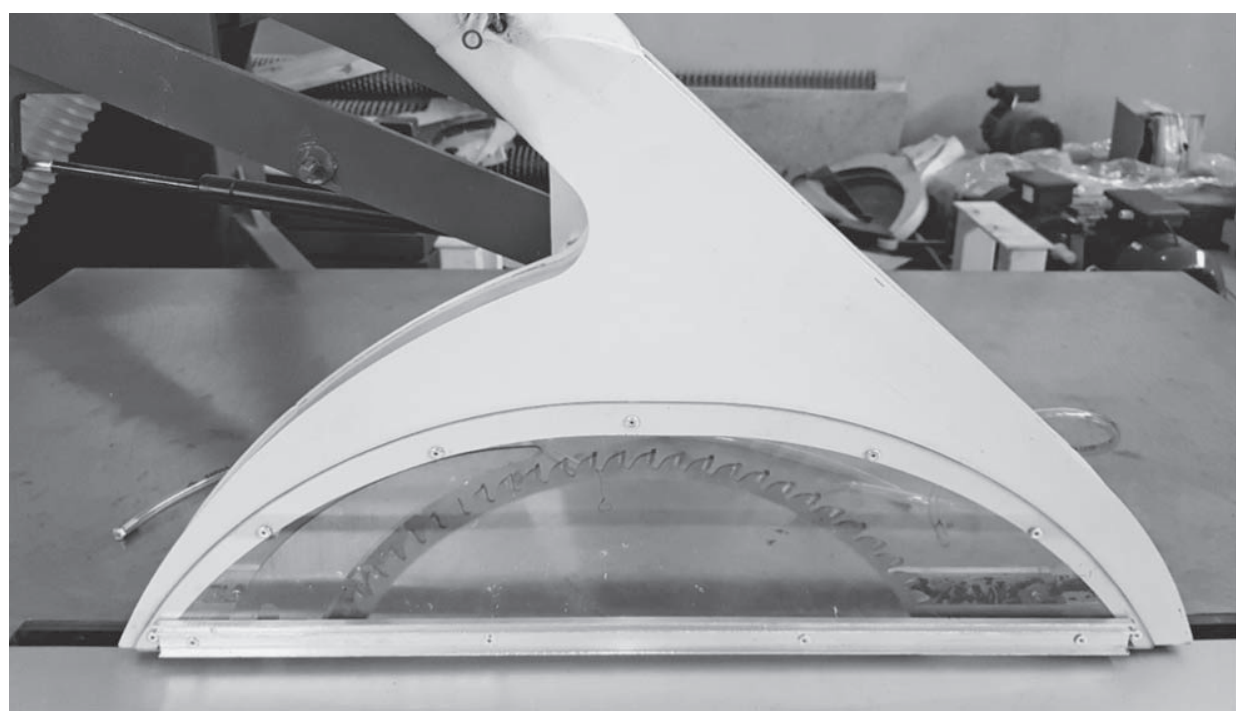

b)

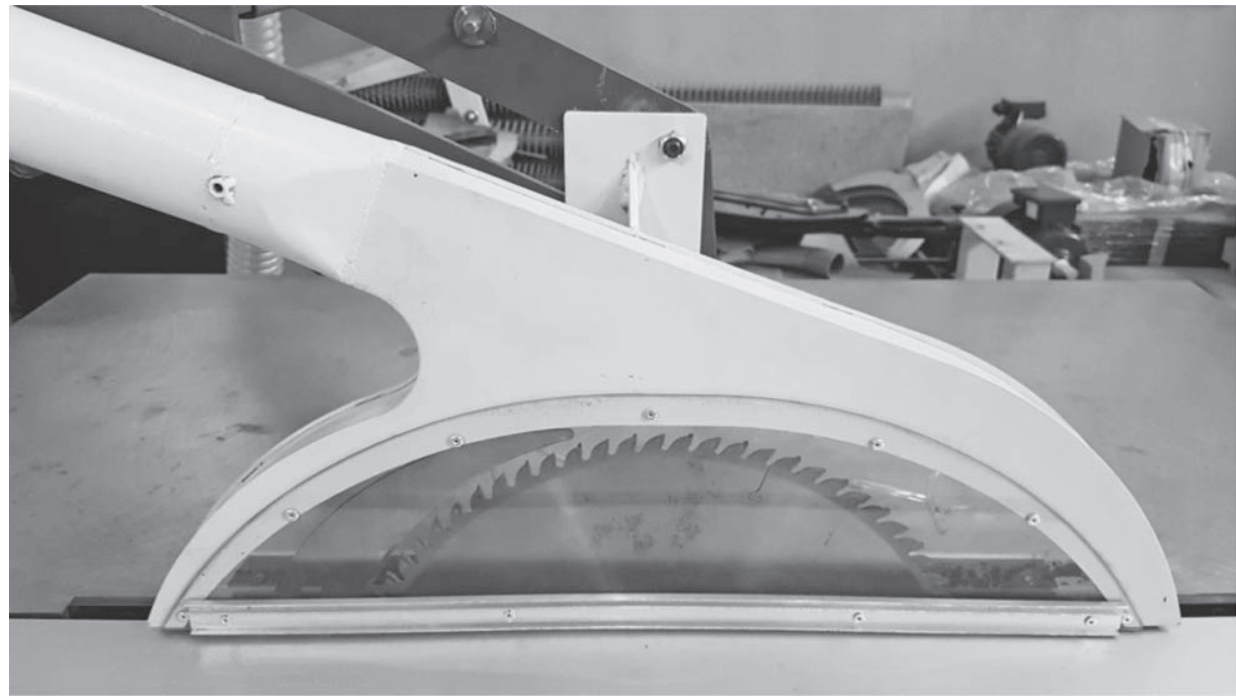

c)

Figure 3 Chosen examples of the upper hood shape: a) base case, b) modified case, c) final case Slika 3. Odabrani primjeri oblika gornjega usisnog ušća: a) početni oblik, b) modificirani oblik, c) konačni oblik

locations were observed with a very low vacuum pressure or even gauge pressure. These are points " $\mathrm{A}$ "-" $\mathrm{B}$ " and "a"-"b" for wide cover and "b*"." $d$ *" in case of the narrow cover. They are located in the zone of the highest influence of the air stream created by the kerf width and rotational speed of the saw blade. That influence at three of the critical points can be seen in Fig. 4 and Fig. 5. Saw blade rotational speed (Fig. 4) adversely affects the pressure distribution, causing disappearance of the desired vacuum pressure. The same result 


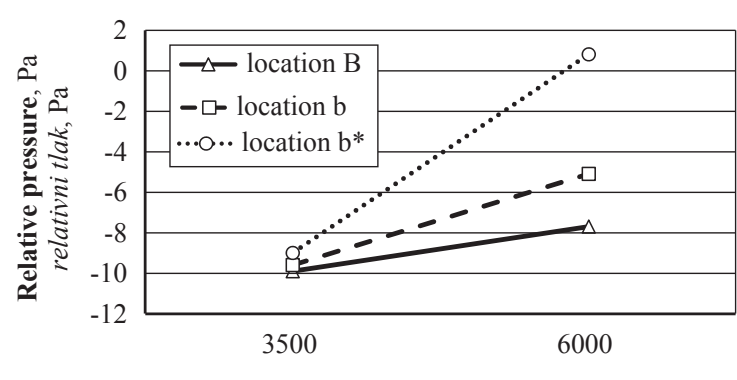

Saw blade rotational speed, $\mathrm{min}^{-1}$

broj okretaja kružne pile, $\min ^{-1}$

Figure 4 Relative static pressure as a function of saw blade rotational speed at different locations for wide and narrow cover of the hood; saw blade No. 1 ( $\varnothing 300 \mathrm{~mm})$, fan motor frequency $50 \mathrm{~Hz}$

Slika 4. Relativni statički tlak kao funkcija brzine vrtnje lista pile na različitim mjestima na širokom i uskom poklopcu usisnog ušća; list pile br. 1 ( $\varnothing 300 \mathrm{~mm})$, frekvencija motora ventilatora $50 \mathrm{~Hz}$

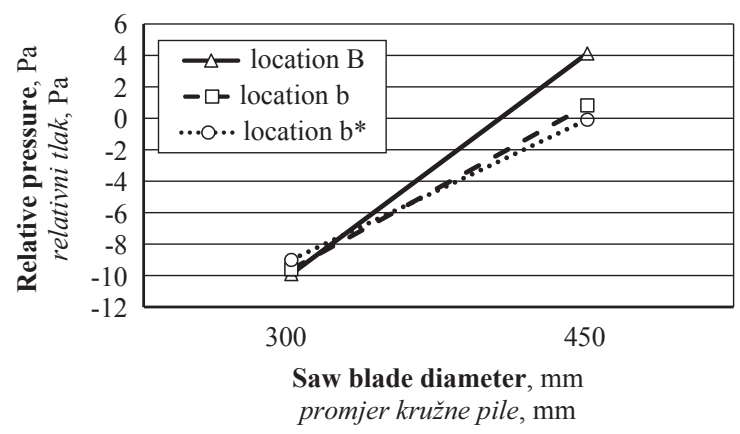

Figure 5 Relative static pressure as a function of saw blade diameter at different locations

for wide and narrow cover of the hood; saw blade rotational speed $3500 \mathrm{~min}^{-1}$, fan motor frequency $50 \mathrm{~Hz}$

Slika 5. Relativni statički tlak kao funkcija promjera lista pile na različitim mjestima na širokom i uskom poklopcu usisnog ušća; frekvencija vrtnje lista pile $3500 \mathrm{~min}^{-1}$, frekvencija motora ventilatora $50 \mathrm{~Hz}$

can be seen by increasing saw blade diameter (Fig. 5) Adverse effect occurs at all critical points.

As can be noticed, when the saw blade operated at the rotational speed of $3500 \mathrm{~min}^{-1}$, there was a small vacuum pressure in locations $B, b$ and $b^{*}$. The value of relative static pressure ranged between - $9 \mathrm{~Pa}$ and -10 $\mathrm{Pa}$. On the other hand, when the saw blade speed was $6000 \mathrm{~min}^{-1}$, the value of relative static pressure changed significanlty and even slight gauge pressure was measured on a narrow cover of the hood (location $b^{*}$ ). For the wide cover of the hood, there was still vacuum pressure, but its value was lower than that for blade rotational speed of $3500 \mathrm{~min}^{-1}$.

Changing saw blade diameter from $\varnothing 300 \mathrm{~mm}$ to $\varnothing 450 \mathrm{~mm}$ caused the transition from vacuum pressure of 9-10 $\mathrm{Pa}$ to gauge pressure of $1 \mathrm{~Pa}$ or $4 \mathrm{~Pa}$ for locations "B" and "b", respectively, and 0 pressure for location " $\mathrm{b}$ *". It is caused by higher linear velocities, occurred during the operation of larger saw blades.

In order to determine the effect of suction, fan speed on relative static pressure at critical locations of fan motor frequencies were changed $\pm 20 \%$, from the

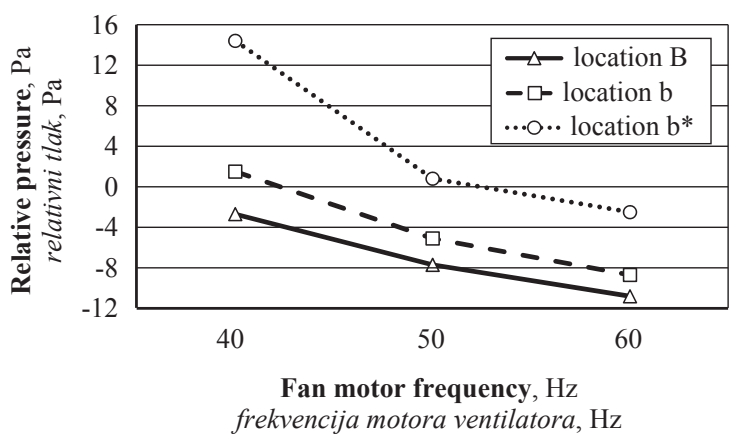

Figure 6 Relative static pressure as a function of fan motor frequency at different locations

for wide and narrow cover of the hood; saw blade No. 1 $(\varnothing 300 \mathrm{~mm})$, rotational speed $6000 \mathrm{~min}^{-1}$

Slika 6. Relativni statički tlak kao funkcija frekvencije motora ventilatora na različitim mjestima na širokom i uskom poklopcu usisnog ušća; list pile br. 1 ( $\varnothing 300 \mathrm{~mm})$, frekvencija vrtnje lista pile $6000 \mathrm{~min}^{-1}$

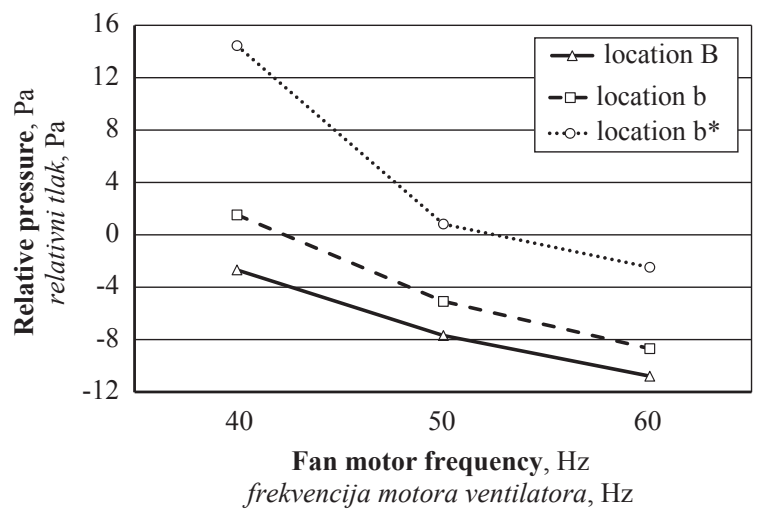

Figure 7 Velocity in outlet channel as a function of fan motor frequency at different saw blade diameters and rotational speed for the wide cover

Slika 7. Brzina u izlaznom kanalu kao funkcija frekvencije motora ventilatora pri različitim promjerima i brzinama vrtnje lista pile za široki poklopac

initial value of $50 \mathrm{~Hz}$ without modification of the suction system. The measurement results for saw blade No. $1(\varnothing 300 \mathrm{~mm})$ and for fan motor frequencies of 40 , 50 and $60 \mathrm{~Hz}$ are shown in Fig. 6. In case of reduced fan motor speed, a very large decrease in vacuum pressure and even the transition to gauge pressure was observed. The value of relative static pressure in locations "B", "b" and "b*" for that case was from +14 Pa to - 3 $\mathrm{Pa}$. This can be explained by the influence of the main air flow in the hood, the scoring saw and the main saw blade rotational speed. On the other hand, increasing fan speed improved pressure distribution in all chosen measurement points and in consequence the performance of the chip removing system was improved.

Velocities in the outlet channel of the hood for both the wide and narrow cover were also measured. The results are shown in Fig. 7 and Fig. 8 for different saw blade diameters, rotational speeds and fan motor frequencies. During the operation of fan motor with the frequency of $50 \mathrm{~Hz}$ for saw blade diameter $\varnothing 300 \mathrm{~mm}$ at rotational speed of $3000 \mathrm{~min}^{-1}$ and $6000 \mathrm{~min}^{-1}$, the velocity differences are small. Even for saw blade di- 


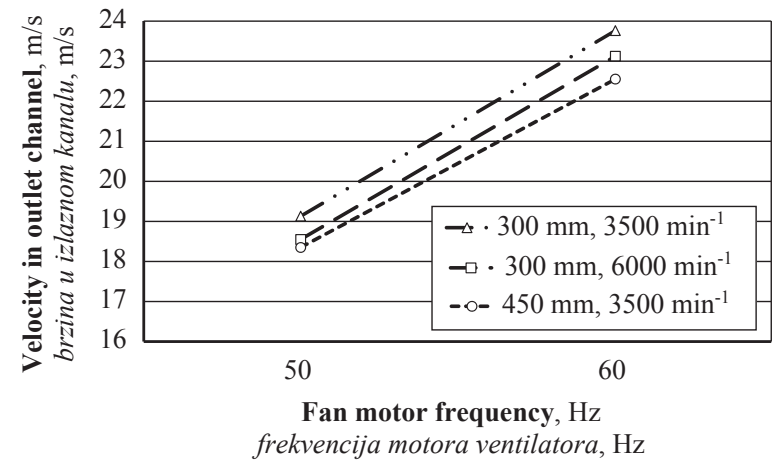

Figure 8 Velocity in outlet channel as a function of fan motor frequency at different saw blade diameters and rotational speed for the narrow cover

Slika 8. Brzina u izlaznom kanalu kao funkcija frekvencije motora ventilatora pri različitim promjerima i brzinama vrtnje lista pile za uski poklopac

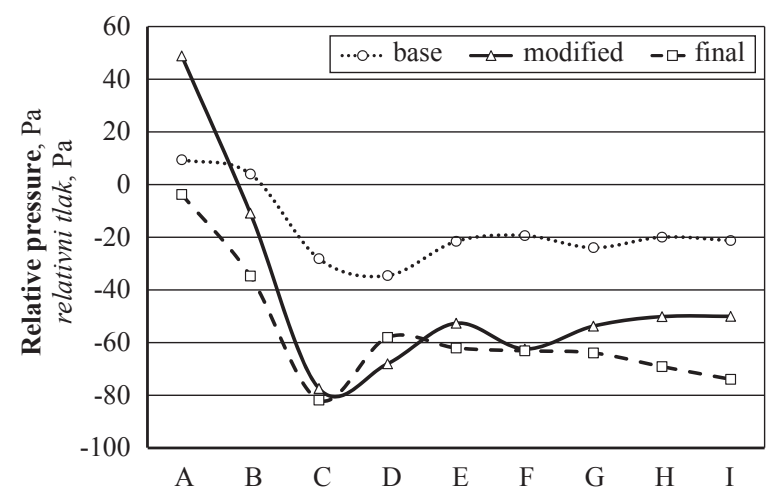

Figure 10 Relative static pressure distribution along the side part of the wide cover

Slika 10. Raspodjela relativnoga statičkog tlaka duž bočnog dijela širokog poklopca

ameter $\varnothing 450 \mathrm{~mm}$, the velocity only slightly increases. Although these differences are due to the diameter and rotational speed of the saw blade, the fan motor frequency is still the most influencing factor. After changing frequency to $60 \mathrm{~Hz}$, the value of velocity in the outlet channel of the hood significantly increased. Velocity improved by about $4 \mathrm{~m} / \mathrm{s}$ in each case after frequency was increased by $20 \%$. However, the obtained velocity was still insufficient according to literature (Dzurenda, 2007).

In order to improve the performance of chip removing system without interfering with the fan structure, several modifications were carried out. The lower shelter shape was modified and changed to obtain smaller volume and, as a result, more efficient air flow and chip removal were achieved. Its leakages were minimized in critical places according to technological possibilities. The upper hood shape was also changed. The examples of its modifications are presented in Fig. $3 \mathrm{~b}$ and $3 \mathrm{c}$. In this element, the outlet channel angle and its inside passage for air flow were modified.

The results of pressure distribution after those modifications are shown for both wide and narrow cover in Fig. 9-11 as "modified" and "final" cases.

The results of measurement presented above show that blade shape, blade rotational speed and fan

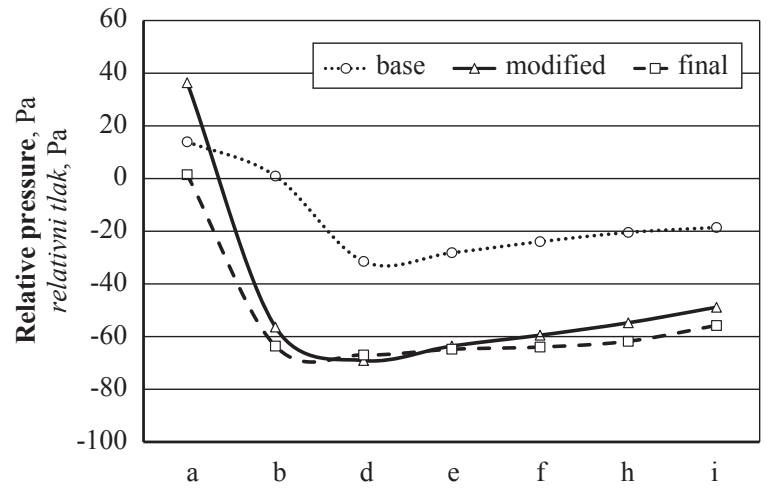

Figure 9 Relative static pressure distribution along the upper part of the wide cover

Slika 9. Raspodjela relativnoga statičkog tlaka duž gornjeg dijela širokog poklopca

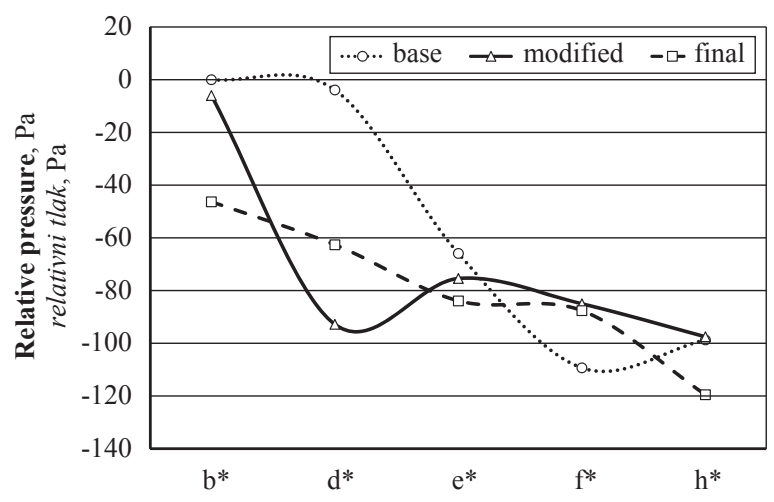

Figure 11 Relative static pressure distribution along the side of the narrow cover

Slika 11. Raspodjela relativnoga statičkog tlaka duž bočnog dijela uskog poklopca

frequency have significant influence on the relative static pressure in chosen locations of the hood covers.

It can be emphasized that higher vacuum pressure in the modified and final hood shape was achieved in comparison with "base case", except for points "A" and "a" for modified case. When wide cover was used, gauge pressure was observed for "base case" and "modified case" in this location. For "final case", a little vacuum pressure was obtained in front of the hood. In the rest of the hood, the satisfactory pressure distribution was noticed without modification of the fan structure. Its final shape and inside construction is presented in Fig. 12.

\section{CONCLUSIONS 4. ZAKLJUČAK}

The existing chip removing system in the analyzed woodworking machine did not provide satisfactory chip extraction from the working area. The experiments proved that, in the area around the tool, insufficient vacuum pressure could hinder the organized transport of wood wastes. After several changes in the system, especially in the upper hood, all parts of the suction system were optimized and modified, except for the fan structure, which provided efficient perfor- 


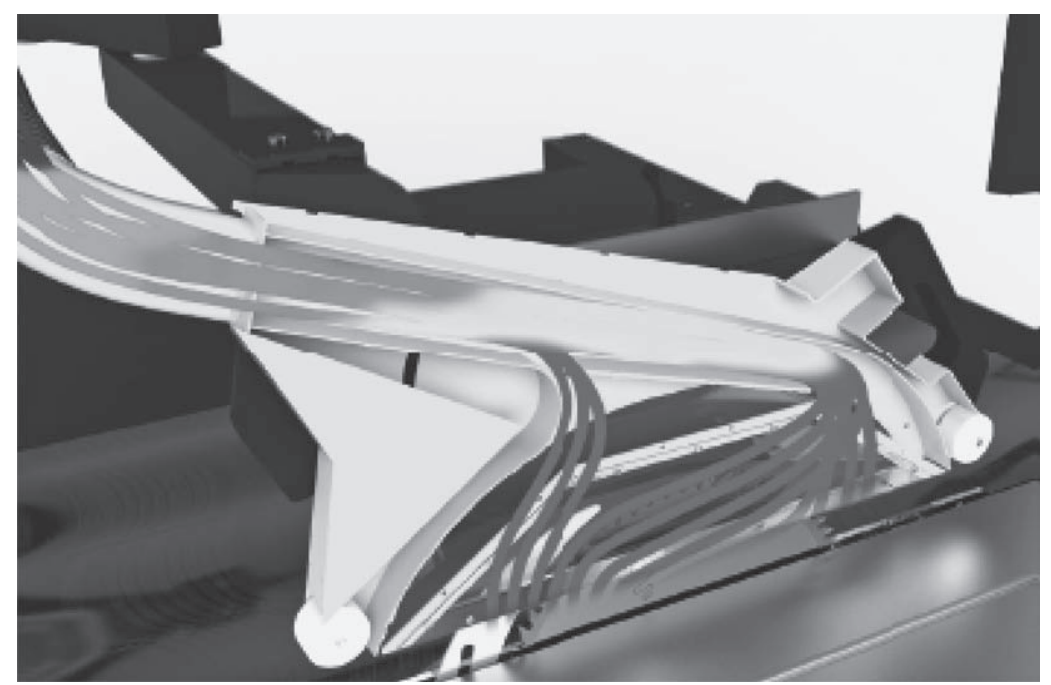

a)

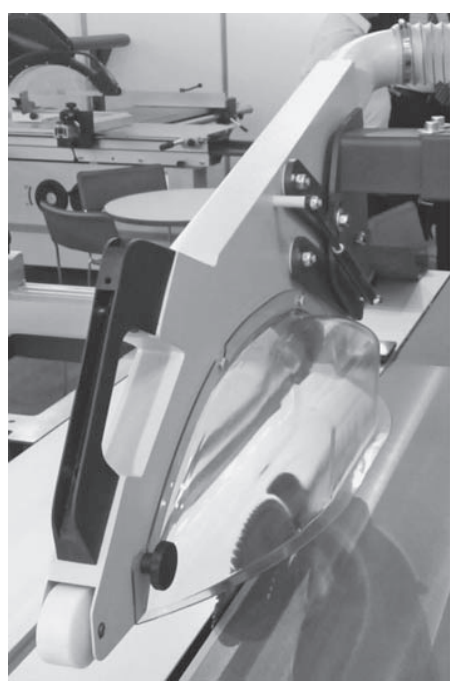

b)

Figure 12 Cross section a) and view b) of final design of the upper hood

Slika 12. Konačni dizajn gornjega usisnog ušća na stolnoj kružnoj pili: a) presjek i b) pogled sprijeda

mance. Eventually, a new design of the chip removing system was obtained. The final construction of the upper hood, which is part of the chip removing system, is shown in Fig. 12.

In order to achieve the most desirable results, however, it is strongly recommended that changes be made in the fan design or its motor resolution be optimized regardless of other modifications.

\section{Acknowledgement - Zahvala}

It is kindly acknowledged that this work has been carried out within the framework of the project POIR.01.01.01-00-05888/15, which has been financially supported by the European Regional Development Fund. The authors would also like to acknowledge the company REMA S. A. in Reszel (Poland), which is the beneficiary of the project, for helping out in the experimental part of this work. The data included in this paper was partially presented during the $23^{\text {rd }} \mathrm{In}$ ternational Wood Machining Seminar, Warsaw, Poland. It could be emphasised that the sliding table saw Fx550, in which the presented solution of the suction system is applied, was awarded with the Gold Medal at the International Fair DREMA in Poznan, Poland in 2017.

\section{REFERENCES}

\section{LITERATURA}

1. Barański, J.; Jewartowski, M.; Wajs, J.; Pikała T., 2016: Experimental analysis of chip removing system in circular sawing machine. Trieskove a Beztrieskove Obrabanie Dreva, 10: 25-29.

2. Beljaková, A., Očkajová, A., 2007: Microscopic analyse of beech sanding dust. In: Proceedings of the $2^{\text {nd }}$ ISC Woodworking techniques. Zagreb, Croatia: Faculty of Forestry, Zagreb, Croatia, pp. 201-206.

3. Beljo Lučić, R.; Kos, A.; Antonović, A.; Vujasinović, E.; Šimičić, I., 2005: Svojstva usitnjenog materijala nastaloga pri mehaničkoj obradi drva. Drvna industrija, 56 (1): 11-19.
4. Dzurenda, L., 2007: Sypká drevná hmota, vzduchotechnická doprava a odlučovanie (Bulk wood mass, air transport and separation). $1^{\text {st }}$ ed., 182 p. Technical University in Zvolen, Slovak Republic (in Slovak).

5. Fujimoto, K.; Takano, T., 2003: Mass concentration and particle size distribution of suspended during circular sawing. The Proceedings of the $16^{\text {th }}$ International Wood Machining Seminar. Matsue, Japan, pp. 724-731.

6. Hemillä, P.; Gottlöber, C.; Weelling, I., 2003: Effect of cutting parameters to dust and noise in wood cutting, laboratory and industrial tests. The Proceedings of the $16^{\text {th }}$ International Wood Machining Seminar. Matsue, Japan, pp. 375-384.

7. Klemet, I.; Detvaj, J., 2007: Technologia prvostupňového spracovania dreva (Technologies of processing of wood). $1^{\text {st }}$ ed., 300 p. Technical University in Zvolen, Slovak Republic (in Slovak).

8. Kohler, B., 1995: Wood dust and cancer. National Report - Health, Safety and Environment, IARC, France.

9. Kopecký, Z.; Rousek, M., 2007: Dustiness in high-speed milling. Wood research, 52 (2): 65-76.

10. Kos, A.; Beljo Lučić, R., 2004: Factors influencing particle size distribution of oak sawdust developed during circular sawing. Trieskove a Beztrieskove Obrabanie Dreva. Technical University in Zvolen, Slovak Republic, 4: 131-137.

11. Očkajová, A., Beljaková, A., 2004: Motion of sanding mean versus granularity of sand wood dust. Trieskove a Beztrieskove Obrabanie Dreva, 4: 163-168.

12. Očkajová, A.; Beljo Lučić, R.; Čavlović, A.; Teraňová, J., 2006: Reduction of dustiness in sawing wood by universal circular saw. Drvna industrija, 57 (3): 119-126.

13. Orłowski, K., 2010: The fundamentals of narrow-kerf sawing: mechanics and quality of cutting. Technical University in Zvolen, Slovak Republic, 123 p.

14. Rogozinski, T.; Dolny, S., 2004: Influence of moisture content on the apparent densities of dust from sanding of alder wood. Trieskove a Beztrieskove Obrabanie Dreva, 4: 205-208.

15. Rončka, J.; Očkajová, A., 2007: The influence of sanding machine type and grit size on granularity of sanding wood dust. $2^{\text {nd }}$ International Scientific Conference "Woodworking techniques". University of Zagreb. Zalesina, Croatia, pp. 289-294. 
16. Wasielewski, R., 1999: Pilarki ramowe z eliptyczną trajektorią prowadzenia pil i hybrydowym wyrównoważonym układem napędu głównego (Frame sawing machines with elliptical saw blades movement and the system balanced). Gdańsk, Politechnika Gdańska, 106 p. (in Polish).

17. Wasielewski, R., Orłowski K., 2002: Hybrid dynamically balanced saw frame drive. Holz als Roh- und Werkstoff. 60 (3): 202-206 https://doi.org/10.1007/s00107-002-0290-4

18. Wieloch, G.; Osajda, M., 2007: Wymiary wiórów z drewna buka powstających przy toczeniu nożem samoobrotowym. International Conference "Wood - machine - tool - workpiece". Poznań, Poland, pp. 53-54 (in Polish).

19. *** 2002: Decision No 1600/2002/EC of the European Parliament and of the Council of laying down the Sixth Community Environment Action Programme. Official Journal of the European Communities, 10.9.2002: L
242/1 - L 242/15 http://eur-lex.europa.eu/legal-content/ EN/TXT/PDF/?uri=CELEX:32002D1600\&from $=$ EN (accessed on July 13, 2017).

\section{Corresponding address:}

Prof. KAZIMIERZ A. ORLOWSKI, Ph.D.

Gdansk University of Technology

Faculty of Mechanical Engineering

Department of Manufacturing Engineering and Automation

G. Narutowicza 11/12

80-233 Gdansk, POLAND

e-mail: korlowsk@pg.gda.pl

ORCID iD: 0000-0003-1998-521X 